\title{
Distribution of Trans-Anethole and Estragole in Fennel (Foeniculum vulgare Mill) of Callus Induced from Different Seedling Parts and Fruits
}

\author{
Abd El-Moneim Mohamed Radwan AFIFY' ${ }^{1}$, Hossam Saad EL-BELTAGI ${ }^{1}$, Anwer Abd El-aziz \\ HAMMAMA', Mahassen Mohamed SIDKY², Omneya Farouk Ahmed MOSTAFA² \\ ${ }^{1}$ Cairo University, Faculty of Agriculture, Department of Biochemistry, P. Box 12613, Gamma st, Giza, Cairo-Egypt; lbltg@yahoo.com \\ ${ }^{2}$ Horticulture Research Institute, ARC, Giza, Egypt
}

\begin{abstract}
In the present study, seeds from local cultivar of fennel were germinated on Murashige and Skoog medium (MS) without plant growth regulators. Different types of explants from the growing seedling such as cotyledonal leaves, hypocotyls, epicotyls and roots were cultured on MS medium, contained different concentrations of 2,4-dichlorophenoxyacetic acid (2,4-D) either alone or with kinetin. Differential responses in the essential oil constituents were observed in the induction and development of callus. The major components of essential oils includes estragole, trans-anethole, limonene and fenchone were studied under different conditions to find out the best methods which could be used to reduce the amount of estragole (not favorite for human consumption) and increase the amount of trans-anethole.
\end{abstract}

Keywords: 2,4-dichlorophenoxyacetic acid (2, 4-D), estragole, fennel, Foeniculum vulgare, kinetin, trans-anethole

\section{Introduction}

Fennel is a plant belonging to the Umbelliferae (Apiaceae) family, known and used by humans since antiquity. Because of its flavor, it was cultivated in the countries surrounding the Mediterranean Sea. Fennel is one of the oldest field crop used by the Egyptian for medicinal purposes. Most of the area cultivated with fennel is located in Midsouthern Egypt (mainly, Elfayom, Menia and Assiut Governorates). The total area cultivated with fennel in Egypt was 2209 feddan in 2006 which produced 3446 tons of ripe dry seeds. Assiut Governorate cultivated about $86 \%$ of this area (A. E. B., 2007).

Only one strain of common fennel (Foeniculum vulgare Mill.) was cultivated in Egypt for the national and international purpose. The cultivar yields big fruits and reasonable percentage of essential oil with particularly high estragole content, but it is poor in fenchone which is an important constituent of the fennel essential oil. Other cultivars were grown under Egyptian environmental conditions, with good yields of fenchone content was found by Massoud (1992). The aims of the present study are to examine the effect of different concentrations of some growth regulators on the ratios of fennel's essential oil components which may be useful in economic production of the plant for medicinal use.

Essential oil of fennel also has an inhibitory effect on the activity of ileum, the urinary bladder and against spasmogens (Saleh et al., 1996). Trans-anethole, estragole, fenchone and limonene are the major constituents of the essential oil of bitter fennel fruits (Bernath et al., 1996; Venskutonis et al., 1996). These, along with some other components, provide the unique aroma and taste. Ttransanethole accounts for the anise taste, estragole the sweetness, fenchone the bitterness, and limonene provides the citrus taste. Commonly, Trans-anethole used for flavor in the food and liquors industry, which considered non-toxic (Barazani et al., 1999). The fresh leaves and dried fruits of this plant are used as a spice for meat, baked and confectionery products, and as a local materia medica in Turkey (Davis, 1972). Sweet fennel (Foeniculum vulgare Mill.var. dulce) is eaten as green salad and used in pharmaceutical, perfumery industries and as flavour of different food preparations such as bread, pastry, confectionery, liqueurs and as ingredients of compound powder of liquorices (Ashraf and Bhatty, 1975; Fenaroli, 1971). The present investigation was under taken to study the differences or similarities in the production of volatile oil contents of fennel (Foeniculum vulgare) in vitro culture and to shed slight on the productivity of trans-anethole and estragole.

\section{Materials and methods}

\section{Experiment}

The present studies were carried out at the "Biotechnology laboratory" Horticulture Research Institute Agricultural Researches Center during 2002 -2006 in corporation of Biochemistry Department Faculty of Agriculture Cairo University. 
80

\section{Explants source}

Fennel fruits (Foeniculum vulgare.L) were obtained from Medicinal and Aromatic plant Research Department, Agricultural Researches Center and surface sterilized for 1 min in 70\% ethyl alcohol then for $20 \mathrm{~min}$ in 30\% commercial bleach (sodium hypochlorite 5.25\%) with two drops of Tween 20, after that rinsed thoroughly for 3 times with sterile distilled water. The sterilized seeds were germinated on MS medium growth regulators-free medium supplemented with $0.7 \%$ agar and 3\% sucrose (Murashige and Skoog, 1962). Glass shell vials (25x95 mm) with polypropylene closures were used. The $\mathrm{pH}$ of the medium was adjusted to $5.7 \pm 1.0$. The medium was autoclaving sterilized for 20 minutes at $121^{\circ} \mathrm{C}$ and $1.2 \mathrm{Kgcm}^{-2}$. The cultures were maintained at $27^{\circ} \mathrm{C} \pm 1.0$ under cool white florescent light $\left(28 \mathrm{mmol} \mathrm{S}^{-1} \mathrm{~m}^{-2}, 16 \mathrm{~h} /\right.$ day $)$. After germination seedlings were used as a source for explants.

\section{Callus induction}

When the seedlings were about $6 \mathrm{~cm}$ height, four types of explants (leaves, hypocotyls, epicotyls and roots segments) were excised. These explants (3-5 mm long) were cultured on MS medium supplemented with kinetin at concentrations of $0.0,0.5$ and $1.0 \mathrm{mg} / \mathrm{l}$ without or with 2 , $4-\mathrm{D}$ at concentrations of $(0.5 \mathrm{~m} \mathrm{~g} / \mathrm{l})$.

The medium contained $3 \%$ sucrose and $0.7 \%$ agar. The cultured were incubated at $23^{\circ} \mathrm{C}$ under $16 \mathrm{~h}$. photoperiod. The factorial treatments of kinetin and 2,4-D in the medium were arranged in randomized complete block experiment with five replicates. The callus tissues were formed after 28 days, and were maintained by sub-culturing every four weeks on the best medium to obtain a large amount of stock calli for experiments (Tawfik, 1995).

\section{Extraction of essential oil from calli}

The different types of calli $(3 \mathrm{~g})$ which formed from the different parts of the seedlings (roots, epicotyls, hypocotyls and leaves) or seeds were extracted by crushing with hexane $(20 \mathrm{ml})$. The supernatant solution was then concentrated to $1 \mathrm{ml}$ and kept at $-20{ }^{\circ} \mathrm{C}$ for further analysis (Barazani et al., 1999).

\section{Method of analysis}

\section{GC-MS Instrument operating conditions}

GC-MS analysis were performed on a HP 6890 Series gas chromatograph coupled to a HP 5973 mass selective detector (HP Technologies, USA). The GC analysis was performed on a HP-5MS ( $80 \mathrm{~m} \times 0.25 \mathrm{~mm}$ I.D., $0.25 \mu \mathrm{m}$ film thickness) capillary column (5\% diphenyl, 95 dimethylpolysiloxane; HP, USA). The oven temperature was programmed from $40^{\circ} \mathrm{C}(3 \mathrm{~min})$ to $60^{\circ} \mathrm{C}$ at a rate of $2^{\circ} \mathrm{C}$ $\mathrm{min}^{-1}$ and from 60 to 120 at rate of $4^{\circ} \mathrm{C} \mathrm{min}{ }^{-1}$ and from 120 to 240 at rate of $7^{\circ} \mathrm{C} \mathrm{min}^{-1}$ final temperature held for $10 \mathrm{~min}$. The MS was operated in the full-scan mode from 35 to $550 \mathrm{~m} / \mathrm{z}$. The identification of essential oil compo- nents was on the basis of comparison of their retention times with standard components and mass spectra with published data (Adams, 2002) and computer matching with WILEY 275 and National Institute of Standards and Technology (NIST 3.0). The instrument control was performed by the HP ChemStation software (HP Technologies, USA).

\section{Results and discussion}

Over than $63.49 \%$ of the germinated fennel fruits were developed normal seedlings on MS growth regulator-free medium after 40 days. The largest amount of callus induced from hypocotyls tissues (Halperin and Wetherell, 1964; Nadal et al., 1989). The data observed that large amount of proliferating callus was on the medium with 2 , 4-D at $0.5 \mathrm{mg} / \mathrm{l}$ with kinetin at 0.5 or $1.0 \mathrm{mg} / \mathrm{l}$ (Tab. 1). The 2, 4-D with kinetin has been used to induce callus in celery (Saranga and Janick, 1991). The callus was compact and had light yellow color.

Tab. 1. Effect of different concentrations of kinetin and 2, 4-D as well as effect of some seedling parts on callusing formation (\%) of fennel (Foeniculum vulgare)

\begin{tabular}{ccccc}
\hline \multirow{2}{*}{$\begin{array}{c}\text { Growth } \\
\text { regulators }\end{array}$} & Root & Epicotyls & Leaves & Hypocotyls \\
\cline { 2 - 5 } Control & $63.2 \pm 1.8^{\mathrm{c}}$ & $68.50 \pm 1.7^{\mathrm{b}}$ & $54.9 \pm 0.5^{\mathrm{b}}$ & $57.5 \pm 2.2^{\mathrm{d}}$ \\
\hline $0.5 \mathrm{mg} / 1$ Kinetin & $61.9 \pm 1.9^{\mathrm{c}}$ & $60.75 \pm 0.9^{\mathrm{c}}$ & $39.5 \pm 0.6^{\mathrm{d}}$ & $45.8 \pm 1.5^{\mathrm{c}}$ \\
\hline $1.0 \mathrm{mg} / 1$ Kinetin & $72.7 \pm 2.9^{\mathrm{b}}$ & $55.25 \pm 1.4^{\mathrm{d}}$ & $52.8 \pm 0.4^{\mathrm{c}}$ & $63.0 \pm 2.4^{\mathrm{c}}$ \\
$0.5 \mathrm{mg} / 12,4-\mathrm{D}$ & $5.46 \pm 0.2^{\mathrm{d}}$ & $76.0 \pm 2.4^{\mathrm{a}}$ & $58.0 \pm 0.6^{\mathrm{a}}$ & $76.5 \pm 3.3^{\mathrm{b}}$ \\
$0.5 \mathrm{mg} / 1$ Kinetin & $78.75 \pm 3.4^{\mathrm{a}}$ & $42.3 \pm 1.1^{\mathrm{c}}$ & $39.0 \pm 0.6^{\mathrm{d}}$ & $100 \pm 4.7^{\mathrm{a}}$ \\
$+0.5 \mathrm{mg} / 12,4-\mathrm{D}$ & & & $52.5 \pm$ & \\
$1.0 \mathrm{mg} / 1$ Kinetin & $6.07 \pm 0.2^{\mathrm{d}}$ & $69.8 \pm 1.8^{\mathrm{b}}$ & $0.4^{\mathrm{c}}$ & $100 \pm 4.9^{\mathrm{a}}$ \\
$+0.5 \mathrm{mg} / 12,4-\mathrm{D}$ & 6.07 . & &
\end{tabular}

Values are expressed as the means \pm SD of three independent assays. Values with different letters in the same column were significantly different $(\mathrm{P} \leq 0.05)$

\section{Chromatographic analysis}

The essential oil contents (\%) ( $\mathrm{mg} / 100 \mathrm{~g})$ for callus of fennel (Foeniculum vulgare)

Data in Tab. 2 showed that the highest oil percentage $(33.0 \mathrm{mg} / 100 \mathrm{~g}$ fresh callus) in callus induced from roots on MS media free hormone, followed by $(30.3 \mathrm{mg} / 100$ $\mathrm{g}$ fresh callus) which produced from callus induced on MS media supplemented with $0.5 \mathrm{mg} / 1$ 2, 4-D and (30 $\mathrm{mg} / 100 \mathrm{~g}$ ) on MS media supplemented with $0.5 \mathrm{mg} / \mathrm{l} \mathrm{ki-}$ netin. While the least oil percentage $(3.3 \mathrm{mg} / 100 \mathrm{~g})$ from callus induced on MS media supplemented with $1.0 \mathrm{mg} / \mathrm{l}$ kinetin plus $0.5 \mathrm{mg} / \mathrm{l} 2$, 4-D. Furthermore the results indicated that the highest oil percentage $(31.3 \mathrm{mg} / 100 \mathrm{~g})$ produced from epicotyls callus induced on MS media supplemented with $0.5 \mathrm{mg} / \mathrm{l}$ kinetin plus $0.5 \mathrm{mg} / \mathrm{l} 2$, 4-D. On the other hand, the least oil percentage $(3.3 \mathrm{mg} / 100$ g) produced from callus induced on MS media supple- 
Tab. 2. Effect of different concentrations of kinetin, 2, 4-D as well as effect of some seedling parts on essential oil contents (\%) $(\mathrm{mg} / 100 \mathrm{~g})$ for callus of fennel (Foeniculum vulgare)

\begin{tabular}{|c|c|c|c|c|}
\hline \multirow{2}{*}{$\begin{array}{l}\text { Growth } \\
\text { regulators }\end{array}$} & \multicolumn{4}{|c|}{ Seedling parts } \\
\hline & Root & Epicotyls & Leaves & Hypocotyls \\
\hline Control & $33.0 \pm 0.8^{a}$ & $8.20 \pm 0.7^{\mathrm{d}}$ & $13.30 \pm 0.8^{b}$ & $22.70 \pm 2.7^{\mathrm{a}}$ \\
\hline $0.5 \mathrm{mg} / \mathrm{L}$ Kinetin & $30.0 \pm 0.9^{\mathrm{b}}$ & $21.30 \pm 1.8^{\mathrm{b}}$ & $4.70 \pm 0.36^{d}$ & $5.30 \pm 0.1^{\mathrm{c}}$ \\
\hline $1.0 \mathrm{mg} / \mathrm{L}$ Kinetin & $7.30 \pm 0.6^{\mathrm{d}}$ & $6.70 \pm 1.2^{\mathrm{c}}$ & $4.70 \pm 0.32^{\mathrm{d}}$ & $5.30 \pm 0.3^{c}$ \\
\hline $0.5 \mathrm{mg} / \mathrm{L} 2,4-\mathrm{D}$ & $30.3 \pm 0.7^{b}$ & $3.30 \pm 0.8^{f}$ & $18.0 \pm 1.92^{\mathrm{a}}$ & $22.00 \pm 2.8^{\mathrm{a}}$ \\
\hline $\begin{array}{l}0.5 \mathrm{mg} / \mathrm{L} \text { Kinetin } \\
+0.5 \mathrm{mg} / \mathrm{L} 2,4-\mathrm{D}\end{array}$ & $11.3 \pm 0.3^{c}$ & $31.30 \pm 2.2^{a}$ & $5.73 \pm 0.31^{\mathrm{c}}$ & $10.00 \pm 4.9^{b}$ \\
\hline $\begin{array}{l}1.0 \mathrm{mg} / \mathrm{L} \text { Kinetin } \\
+0.5 \mathrm{mg} / \mathrm{L} 2,4-\mathrm{D}\end{array}$ & $3.3 \pm 0.2^{\mathrm{c}}$ & $12.00 \pm 0.9^{c}$ & $3.67 \pm 0.19^{c}$ & $5.54 \pm 0.4^{c}$ \\
\hline
\end{tabular}

Values are expressed as the means \pm SD of three independent assays. Values with different letters in the same column were significantly different $(\mathrm{P} \leq 0.05)$

mented with $0.5 \mathrm{mg} / \mathrm{l} 2$, 4-D. At the contrast the same concentration of 2, 4-D produced the highest oil percentage $(18.0 \mathrm{mg} / 100 \mathrm{~g})$ in the callus induced from leaves. Regarding the effect of different concentrations of kinetin and 2,4-D, the results observed that callus induced from leaves gave the lower oil percentages comparing with the other seedling parts, while it gave $(3.67 \mathrm{mg} / 100 \mathrm{~g})$ from callus induced on MS media supplemented with $1.0 \mathrm{mg} / \mathrm{l}$ kinetin plus $0.5 \mathrm{mg} / 1$ 2, 4-D. In Tab. 2 it can be observed that kinetin at concentration $0.5 \mathrm{mg} / \mathrm{l}$ or $1.0 \mathrm{mg} / \mathrm{l} \mathrm{de}-$ creased the production of callus oil which induced from hypocotyls, it indicated $(5.30 \mathrm{mg} / 100 \mathrm{~g})$ at both concen- trations. While, the highest oil percentage $(22.70 \mathrm{mg} / 100$ g) recorded on MS media free hormone. Lavender plant essential oil yield was significantly promoted as result of foliar application of kinetin (Youssef and Talaat, 1998). Our results are in agreement with El-Keltawi and Cratean (1987), who illustrated that, the increase in essential oil of lamiaceae plants is attributable in part to the influence of cytokinin on monoterpene metabolism as it have been rationalized largely in terms of an alternation of monoterpene reducates. According to the oil percentage (\%) which produced from different seedling parts, the results indicated that callus induced from root contains the highest oil percentage $(33.0 \mathrm{mg} / 100 \mathrm{~g})$ followed by callus induced from epicotyls $(31.30 \mathrm{mg} / 100 \mathrm{~g})$, while the oil percentage of fruits which represents $3.46 \mathrm{~g} / 100 \mathrm{~g}$. On the other hand, it was reported that bitter fennel oils were 1.2, 1.7, 2.1,2.2 and 5.6\% in stem, leaves, flowering umbels, flowers and ripe fruits respectively (Akgül and Bayrak, 1988).

The relative percentage composition of the volatile oils from fruits and callus induced from different seedling parts of fennel (Foeniculum vulgare) on MS media free hormone

The identified components of bitter fennel volatile oils and their percentages by GC- Mass are listed in Tab. 4 and 5.

Trans-anethole is an important component for the aroma, because of its sweet taste and many studies con-

Tab. 3. The parent and degradable $M / Z$ ions of essential oils of fennel (Foeniculum vulgare)

\begin{tabular}{|c|c|c|c|c|c|c|c|c|c|c|c|}
\hline & T-anethole & Estragole & Fenchone & Limonene & Fenchyl acetate & Anisaldehyde & Camphor & Carene & P-cymene & $\beta$-myrcene & $\alpha$-Pinene \\
\hline \multirow{7}{*}{$M / Z$} & 149 & 148.2 & 81 & 97 & 81 & 135 & 97 & 123 & 115 & 97 & 93 \\
\hline & 132 & 121 & 55 & 73 & 55 & 129 & 74 & 96 & 97 & 73 & 74 \\
\hline & 113 & 104 & 29 & 43 & 29 & 112 & 43 & 74 & 74 & 41 & 43 \\
\hline & 83 & 76 & & 26 & & 83 & 27 & 55 & 43 & 25 & 26 \\
\hline & 57 & 58 & & & & 57 & & 29 & 26 & & \\
\hline & 29 & 41 & & & & 29 & & & & & \\
\hline & & 20 & & & & & & & & & \\
\hline
\end{tabular}

Tab. 4. Relative percentage composition of the volatile oils from callus induced from different seedling parts of fennel (Foeniculum vulgare)

\begin{tabular}{cccccc}
\hline Component & Fruits & Callus induced from roots & Callus induced from leaves & Callus induced from hypocotyls & Callus induced from epicotyls \\
\hline Trans-anethole & 0.871 & 58.726 & 82.490 & 66.772 & 68.293 \\
\hline Estragole & 85.599 & - & 7.263 & 4.114 & 16.098 \\
Fenchone & 3.215 & 8.310 & - & - & - \\
\hline Limonene & 4.019 & - & 3.502 & - & - \\
Fenchylacetate & 0.268 & - & - & - & - \\
Anisaldehyde & 0.536 & 7.479 & 5.447 & 2.848 & 6.829 \\
Camphor & 0.201 & 4.155 & - & - & - \\
Carene & 3.516 & 7.202 & - & - & - \\
P-cymene & 0.6698 & 4.432 & - & - & - \\
$\beta$-myrcene & 0.402 & 3.878 & - & - & - \\
a-pinene & 0.301 & - & - & 26.266 & - \\
Unknown & 0.402 & 5.817 & 1.297 & 8.78 \\
\hline
\end{tabular}

Values calculated as percentages of the total fennel volatile oil composition 
Tab. 5. Effect of different concentrations of kinetin, 2, 4-D on relative percentage composiotion of the volatile oils from callus induced from different seedling parts of fennel (Foeniculum vulgare)

\begin{tabular}{|c|c|c|c|c|c|c|c|c|c|c|c|c|c|}
\hline Seedling parts & Growth regulators & T-anethole & Estragole & Fenchone & Limonene & Fenchyl acetate & Anisaldehyde & Camphor & Carene & $P$-cymene & $\beta$-myrcene & $\alpha$-Pinene & Unknown \\
\hline \multirow{5}{*}{ Roots } & $0.5 \mathrm{mg} / \mathrm{l} \mathrm{kinetin}$ & 0.88 & 97.74 & - & - & 0.39 & - & - & - & - & - & - & 0.99 \\
\hline & $1.0 \mathrm{mg} / \mathrm{l} \mathrm{kinetin}$ & 3.14 & 85.63 & - & - & 0.07 & - & - & - & - & - & - & 11.16 \\
\hline & $0.5 \mathrm{mg} / 2,4-\mathrm{D}$ & 22.9 & 19.89 & 5.57 & - & 3.76 & - & 12.34 & - & - & - & - & 35.55 \\
\hline & $0.5 \mathrm{mg} / \mathrm{lkinetin}+0.5 \mathrm{mg} / 2,4-\mathrm{D}$ & 46.33 & 2.48 & 3.24 & 4.33 & 8.49 & - & 3.25 & - & - & - & - & 31.88 \\
\hline & $1.0 \mathrm{mg} / \mathrm{l}$ kinetin $+0.5 \mathrm{mg} / 2,4-\mathrm{D}$ & 56.53 & 5.29 & 12.574 & - & - & - & 9.06 & 1.51 & - & - & - & 15.036 \\
\hline \multirow{5}{*}{ Epicotyls } & $0.5 \mathrm{mg} / \mathrm{l} \mathrm{kinetin}$ & 12.94 & 1.18 & 2.76 & 2.76 & 1.67 & - & - & 5.09 & - & 2.24 & 1.33 & 70.12 \\
\hline & $1.0 \mathrm{mg} / \mathrm{l} \mathrm{kinetin}$ & 0.39 & 71.82 & 0.8 & - & 0.53 & 0.64 & 2.62 & 3.59 & 1.25 & 0.57 & 0.26 & 17.53 \\
\hline & $0.5 \mathrm{mg} / 2,4-\mathrm{D}$ & 49.2 & 11.44 & - & - & 1.59 & 4.07 & 6.14 & - & - & - & - & 29.16 \\
\hline & $0.5 \mathrm{mg} / \mathrm{lkinetin}+0.5 \mathrm{mg} / 2,4-\mathrm{D}$ & 73.53 & 2.03 & - & - & - & - & 1.98 & - & - & - & 3.21 & 19.25 \\
\hline & $1.0 \mathrm{mg} / \mathrm{l} \mathrm{kinetin}+0.5 \mathrm{mg} / 2,4-\mathrm{D}$ & 57.79 & 2.5 & 5.5 & 2.3 & 13.7 & - & 11.08 & 3.18 & - & - & - & 3.95 \\
\hline \multirow{5}{*}{ Leaves } & $0.5 \mathrm{mg} / \mathrm{l}$ kinetin & 15.68 & 83.3 & - & - & 0.20 & 0.82 & - & - & - & - & - & - \\
\hline & $1.0 \mathrm{mg} / \mathrm{l} \mathrm{kinetin}$ & 61.79 & 0.75 & - & - & 2.25 & - & 1.01 & - & 0.51 & 3.21 & 6.12 & 24.36 \\
\hline & $0.5 \mathrm{mg} / 2,4-\mathrm{D}$ & 43.69 & 12.55 & 2.32 & 7.6 & 0.7 & - & 3.73 & - & - & 3.23 & 3.54 & 22.62 \\
\hline & $0.5 \mathrm{mg} / \mathrm{lkinetin}+0.5 \mathrm{mg} / 2,4-\mathrm{D}$ & 6.55 & 89.53 & 2.18 & - & - & - & 1.73 & - & - & - & - & - \\
\hline & $1.0 \mathrm{mg} / \mathrm{l} \mathrm{kinetin}+0.5 \mathrm{mg} / 2,4-\mathrm{D}$ & 97.54 & 0.21 & 0.21 & - & 0.77 & - & 0.42 & - & - & - & - & 0.82 \\
\hline \multirow{5}{*}{ Hypocotyls } & $0.5 \mathrm{mg} / \mathrm{l}$ kinetin & 2.88 & 6.94 & 2.03 & - & 1.69 & - & - & 3.71 & - & - & - & 82.75 \\
\hline & $1.0 \mathrm{mg} / \mathrm{l} \mathrm{kinetin}$ & 2.5 & 8.44 & 1.02 & 2.51 & - & 21.93 & 6.77 & 3.28 & - & - & - & 53.55 \\
\hline & $0.5 \mathrm{mg} / 2,4-\mathrm{D}$ & 26.37 & 8.92 & 16.29 & 5.85 & 4.57 & 2.06 & 3.55 & 6.83 & - & - & 0.11 & 25.45 \\
\hline & $0.5 \mathrm{mg} / \mathrm{lkinetin}+0.5 \mathrm{mg} / 2,4-\mathrm{D}$ & 15.28 & 83.95 & - & - & 0.3 & - & 0.48 & - & - & - & - & - \\
\hline & $1.0 \mathrm{mg} / \mathrm{l} \mathrm{kinetin}+0.5 \mathrm{mg} / 2,4-\mathrm{D}$ & 98.72 & - & - & - & 0.88 & - & 0.41 & - & - & - & - & - \\
\hline
\end{tabular}

Values calculated as percentages of the total fennel volatile oil composition 
firmed that trans-anethole constitutes about $90-95 \%$ of the total fennel volatile oil composition. The result in Tab. 4 shows that the relative percentage of trans-anethole which represents the major component of callus induced from roots, leaves, hypocotyls and epicotyls on MS media free hormone which represents 58.726, 82.49, 66.772 and $68.293 \%$ respectively. On the other hand in fruit, the contents of trans-anethole was $0.871 \%$ which considered very low concentration compare to different induced of callus. The mass spectra of trans- anethole and estragole are quite similar as shown in and Tab. 3. Estragole represents the major components in fruits $85.599 \%$ and arranged 7.263 , 4.114 and $16.098 \%$ in leaf, hypocotyls and epicotyls respectively and it could not be detected in callus induced from roots. Limonene is conferred a fresh smell, it was represent in fruit (4.019\%) and in callus induced from leaf (3.502\%) only but it was absent in callus induced from root, hypocotyls and epicotyls. Callus from different parts contained high trans-anethole content and small amounts of estragole and vice-versa, while fruit contained more estragole.

Fruits with an intense, sweet and aniseed taste contained more trans-anethole, while samples with a delicate and soft taste contained more estragole (Miraldi, 1999). Fennel which grows in habitats with high summer temperatures and low humidity exhibited the highest transanethole content 55 and $74 \%$, respectively, with the lowest level of estragole $8 \%$ of the pick area (Brazani et al., 1999).

C-MS spectral analysis of fennel essential oils component proved the presence of trans- anethole, estragole, fenchone, limonene, fenchyle acetate, anisaldehyde, camphor, carene, $p$-cymene, $\beta$-myrcene and $\alpha$-pinene. The major component trans- anethole has $\mathrm{M} / \mathrm{Z}$ of 149 and its fragment as, 132, 113, 83, 57 and 29. The parent and degradable $\mathrm{M} / \mathrm{Z}$ ions of all detected essential oils were shown in Tab. 3. The identification of fruit's volatile oil was carried out by comparing both mass spectra and retention times. One of the main components of the fennel is fenchone which represents $(3.215 \%)$ in fruits and it was identified only in callus induced from root (8.31\%). Fenchone has a pungent and camphorate odour; it is present especially in bitter fennel. Noteworthy differences were also recorded in the precentage of anisaldehyde an autoxidation product of trans-anethole, ranged from $2.848 \%$ in callus induced from hypocotyls, and repredent $5.447 \%$ in callus induced from leaf, to the intermediate $6.829 \%$ in callus induced from epicotyls, up to the highest $7.479 \%$ in callus induced from root, while it was very low in fruits $(0.536 \%)$.

In callus induced from root the present work found the most essential oils which existed in fruits with high percentage like camphor (4.155\%), carene (7.202\%), p-cymene $(4.432 \%)$ and $\beta$-myrcene $(3.878 \%)$ but in fruits they showed $0.201 \%, 3.516 \%, 0.6698 \%, 0.402 \%$ respectively. $\alpha$-pinene was the monoterpene hydrocarbon $(0.301 \%)$ which identified only in fruits. Percentage of anethole ranged from 86 to $88 \%$ in sweet fennel oil and $74 \%$ in bitter fennel oil while limonene was only 4 and 2\% respectively in sweet and bitter fruits (Arslan et al., 1989). In Foeniculum vulgare var. dulce, anethole was $69 \%$ in fruits and $39 \%$ herb oil, the relative percentage of limonene being 8 and $20 \%$ in the fruits and herb oil (Embong et al., 1977). The volatile oils of callus which induced from root were relatively differences from other callus seven constituents were detected of which the major compound was trans-anethole at $58.726 \%$. And the other compounds were relatively high concentrations from the other callus. They are fenchone, anisaldehyde, camphor, careen, p-cymene, $\beta$-myrcene and $\alpha$-pinene (8.310, 7.479, 4.155, $7.202,4.432$ and $3.878 \%$, respectively). However estragole contents were not available in callus induced from root.

\section{Effect of different concentrations of kinetin, 2,4-D on relative percentage composition of the volatile oils from callus induced from different seedling parts of fennel (Foeniculum vulgare)}

\section{Root explants}

Growth regulators have different affects on the callus essential oil contents (Tab. 5). The results indicated that kinetin at concentrations 0.5 and $1.0 \mathrm{mg} / \mathrm{l}$ formed poor oil which consists of only three kinds of volatile oil such as $\mathrm{t}$-anethole, estragole and fenchyl acetate at percentages $(0.88,97.74$ and 0.39$)$ respectively in samples induced from media supplemented with $0.5 \mathrm{mg} / \mathrm{l}$ kinetin.

While their percentages were $(3.14,85.63$ and 0.07$)$ respectively in samples induced from media supplemented with $1.0 \mathrm{mg} / \mathrm{l}$ kinetin. Moreover in media supplemented with $0.5 \mathrm{mg} / 1$ 2,4-D the essential oil contents were t-anethole, estragole, fenchone, fenchylacetate and camphor at percentages $(22.9,19.89,5.57,3.76$ and 12.34$)$ respectively. Comparing with callus induced on MS media free hormone, there was no estragole content and $\mathrm{t}$-anethole content recorded as $58.7 \%$.

Furthermore, it was found that the combination between 2,4-D $(0.5 \mathrm{mg} / \mathrm{l})$ and kinetin $(0.5 \mathrm{mg} / \mathrm{l})$ produced $\mathrm{t}$-anethole, estragole, fenchone, limonene fenchyl acetate and camphor at percentages $(46.33,2.48,3.24,4.33,8.49$ and 3.25) respectively. The results revealed that t-anethole, estragole, fenchone, camphor and carene were produced from callus induced on MS media supplemented with $0.5 \mathrm{mg} / \mathrm{l}, 2,4-\mathrm{D}$ and $1.0 \mathrm{mg} / \mathrm{l} \mathrm{kinetin}$ at percentages $(56.53$, $5.29,12.574,9.06$ and 1.51 ) respectively. From the above data it can be concluded that kinetin leads to form high percentage from estaragole ( 97.74 and 85.63 ) respectively and the lowest content from t-anethole (0.88and 3.14) respectively. It is clear that 2,4-D influenced higher percentage of $t$-anethole (22.9) than estragole (19.89). The increase in oil percentage due to kinetin may be referred to their functions in preventing the hydrolytic break down of oil naturally occurring in the plants as a result of the bal- 
84

ance between such hormones and the endogenous plant hormones (Schive and Sisler, 1976).

\section{Epicotyls explants}

Data in Tab. 5 showed that kinetin at concentration $0.5 \mathrm{mg} / \mathrm{l}$ induced callus contain different components of essential oil such as t-anethlole (12.94\%), estragole (1.18\%), fenchone $(2.76 \%)$, limonene (2.76\%), fenchyl acetate (1.67\%), carene (5.09\%), $\beta$-myrcene (2.24\%) and $\alpha$-pinene $(1.33 \%)$. While using kinetin at concentration $1.0 \mathrm{mg} / \mathrm{l}$ induced callus contain $\mathrm{t}$-anethole $(0.39 \%)$, estragole (71.82\%), fenchone (0.8\%), fenchyl acetate $(0.53 \%)$, anisaldehyde $(0.64 \%)$, camphor $(2.62 \%)$, carene (3.59\%), P-cymene (1.25\%) $\beta$-myrcene $(0.57 \%)$ and $\alpha$-pinene $(0.26 \%)$. It can be observed from Tab. 4 that 2,4-D at concentration $0.5 \mathrm{mg} / \mathrm{l}$ alone or with $(0.5 \mathrm{mg} / \mathrm{l}$ and $1.0 \mathrm{mg} / \mathrm{l})$ kinetin produced a very high percentage of estragole $(49.2 \%, 73.53 \%$ and $57.79 \%)$ respectively, and low percentage of $\mathrm{t}$-anethole $(11.44 \%, 2.03 \%$ and $2.5 \%)$ respectively. Other components at using 2,4-D $(0.5 \mathrm{mg} / \mathrm{l})$ gave lower concentrations like fenchyl acetate (1.59\%), anisaldehyde (4.07\%) and camphor (6.14\%). Moreover, camphor and $\alpha$-pinene recorded $(1.98 \%)$ and $(3.21 \%)$ in callus induced on MS media supplemented with $0.5 \mathrm{mg} / \mathrm{l}$ 2, 4-D and $0.5 \mathrm{mg} / \mathrm{l}$ kinetin. Fenchone, limonene, fenchyl acetate, camphor and careen recorded 5.5\%, 2.3\%, $13.7 \%, 11.08 \%$ and $3.18 \%$ in callus induced on MS media supplemented with $0.5 \mathrm{mg} / \mathrm{l} 2,4-\mathrm{D}$ and $1.0 \mathrm{mg} / \mathrm{l}$ kinetin. Type of explant had also a role in affecting essential oil contents.

Epicotyls explants formed the highest percentage of estragole by using kinetin at concentration $(1.0) \mathrm{mg} / \mathrm{l}$, while the epicotyls exlplants formed the highest percentage of $\mathrm{t}$-anethole by using $2,4-\mathrm{D}$ at concentration $0.5 \mathrm{mg} / \mathrm{l}$ only or with kinetin at the same concentration or at $1.0 \mathrm{mg} / \mathrm{l}$ (Tab. 5). Comparing with callus induced on MS media free hormone, estragole content recorded $16.098 \%$ and $\mathrm{t}$-anethole recorded $68.29 \%$. These results had been discussed by Sangwan et al. (2001), who mentioned that one of the most important characteristics of oil accumulation is its dependence on the developmental stage/phase of the plant as well as its concerned part/organ, tissue and the cells.

\section{Leaves explants}

Comparing the effect of kinetin and 2,4-D, the results showed that kinetin at concentration $0.5 \mathrm{mg} / \mathrm{l}$ was capable of producing $\mathrm{t}$-anethole (15.68\%), estragole (83.3\%), fenchyl acetate $(0.20 \%)$ and anisaldehyde $(0.82 \%)$. While, kinetin at concentration $1.0 \mathrm{mg} / \mathrm{l}$ produced $\mathrm{t}$-anethole (61.79\%), estragole (0.75\%), fenchyl acetate (2.25\%), camphor(1.01\%), P-cymene (0.51\%), $\beta$ - myrecene (3.21\%) and $\alpha$-pinene $(6.12 \%)$. Comparing the effect of $2,4-\mathrm{D}$, the results showed that $2,4-\mathrm{D}$ at concentration $0.5 \mathrm{mg} / \mathrm{l}$ was capable of producing $\mathrm{t}$-anethole $(43.69 \%)$, estragole (12.55\%), fenchone (2.32\%), limonene (7.6\%), fenchyl acetate $(0.70 \%)$, camphor(3.73\%), $\beta$-myrecene (3.23\%) and $\alpha$-pinene $(3.54 \%)$. Moreover, the media were supplemented with $2,4-\mathrm{D}(0.5 \mathrm{mg} / \mathrm{l})$ and kinetin at concentrations $(0.5 \mathrm{mg} / \mathrm{l}$ and $1.0 \mathrm{mg} / \mathrm{l})$ produced callus contain $\mathrm{t}$-anethole (6.55\% and $97.54 \%)$, estragole $(89.53 \%$ and $0.21 \%)$, fenchone $(2.18 \%$ and $0.21 \%$ ) and camphor $(1.73 \%$ and $0.42 \%)$ respectively. Fenchyl acetate existed only in callus induced on MS media supplemented with kinetin $(1.0 \mathrm{mg} / \mathrm{l})$ and 2 , 4-D (0.5mg/l). Comparing with callus induced on MS media free hormone, estragole content recorded $7.26 \%$, while y-anethole content recorded $82.49 \%$.

\section{Hypocotyls explants}

According to the effect of kinetin on the relative percentage composition of the volatile oils from callus induced from hypocotyls. The results revealed that kinetin at concentrations $(0.5 \mathrm{mg} / \mathrm{l}$ and $1.0 \mathrm{mg} / \mathrm{l})$ produced estragole as a higher percentage (6.94 and 8.44) respectively than $\mathrm{t}$ anethole which recorded (2.88 and 2.5) respectively. While anisaldehyde recorded the highest percentage $(21.93 \%)$ in callus induced on MS media supplemented with $1.0 \mathrm{mg} / \mathrm{l}$ kinetin. Furthermore, 2, 4-D at concentration $0.5 \mathrm{mg} / \mathrm{l}$ gave the highest percentage of estragole (26.37\%), while $\mathrm{t}$-anethole was (8.92\%). In the present analysis, fenchone was found in a remarkable amount (16.29\%). It can be observed from the results given in Tab. 5 that $0.5 \mathrm{mg} / \mathrm{l} \mathrm{kinetin}$ with $0.5 \mathrm{mg} / \mathrm{l} 2,4-\mathrm{D}$ produced $\mathrm{t}$-anethole at $15.28 \%$ and estragole at $83.95 \%$, while $0.5 \mathrm{mg} / \mathrm{l} 2,4-\mathrm{D}$ with $1.0 \mathrm{mg} / \mathrm{l}$ kinetin produced $\mathrm{t}$-anethole at $98.72 \%$ and no estragole content was observed. Comparing with callus induced on MS free hormone, estragole content recorded $4.11 \%$, while $t$-anethole content recorded $66.77 \%$.

In generally (Tab. 5) there are a number of compounds present in different parts of fennel, especially the components of the essential oil such as various phenylpropanoids and terpenes (Bilia et al., 2002). Moreover, using MS media supplemented with $1.0 \mathrm{mg} / \mathrm{l}$ kinetin plus $0.5 \mathrm{mg} / \mathrm{l}$ 2,4-D induced callus which is rich in $\mathrm{t}$-anethole and poor in estragole for all seedling parts under this study, which were the best for cultivation, and it could be induced into a breeding program in the future for commercial production.

The proportion of fenchone in the volatile fraction of both roots and hypocotyls extracts was a similar order and greater than that in fruits extract. These results are disagreement with previous reports of essential oils of bitter and sweet fennel (Akgül and Bayrak, 1988; Baldrich et al., 1986). From another point of view, it can be observed that samples with a high Trans-anethole content contained small amounts of estragole and vice versa, these results are in agreement with Miraidi (1999). Anisaldehyhe, a degradation product of trans- anethole was also a high content in hypocotyls callus induced on MS media supplemented with $1.0 \mathrm{mg} / \mathrm{l}$ kinetin (Bilia et al., 2000). The results under discussion clearly show that the ratio between trans- 
anethole and estragole differs between chemotypes ( $\mathrm{Ba}$ razani, et al., 2002; Muckensturm et al., 1997). Estragole is nowadays recognized as a potential human carcinogen (Vincenzi, et al., 2000). The over all result could be to change in the chemotype in terms of reduced quality of fennel and increased health risk. Additionally, estragole and fenchone are known to be carcinogenic and epileptogenic respectively (Burkhard et al., 1999; Phillips, 1994). On the other hand, the insecticidal action of estragole and fenchone against Soryzae adults was very rapid, whereas only anethole exhibited rapid insecticidal action against $\mathrm{L}$ serricorne adults (Kim and Ahn, 2001).

Estragole and trans-anethole are the major constituents of the essential oils of bitter fennel chemotypes (Foeniculum vulgare Mill. var. vulgare) (Gross et al., 2002). Cell free extracts from bitter fennel tissues display o-methyltransferase activities able to in-vitro methylate chavicol and trans-anol to produce estragole and trans-anethole, respectively. These results indicated that an apparent association between the levels of estragole and trans-anethole in the different plant parts. Thus the present results indicate that fruits had the most substantial content of estragole and the callus had the most substantial content of transanethole. Foeniculum vulgare var. vulgare presents great composition differences with varying populations with the aim of clarifying the status of var. vulgare, the proposed to subdivide it into three chemotypes according to their relative compositions (Muckensturm et al., 1997). They called them chemotype estragole, chemotype estragole/anethole and chtyp. anethole. According to that our results divided into two chemotypes in the following:

\begin{tabular}{cccc}
\hline $1-$ & $\begin{array}{c}\text { chemotype } \\
\text { estragole }\end{array}$ & $\begin{array}{c}\text { Estragole is the major } \\
\text { compound }\end{array}$ & $\begin{array}{c}\text { The } \\
\text { fruits }\end{array}$ \\
\hline 2- & $\begin{array}{c}\text { chemotype } \\
\text { anethole }\end{array}$ & $\begin{array}{c}\text { t-anethole is the } \\
\text { major compound }\end{array}$ & $\begin{array}{c}\text { The } \\
\text { callus }\end{array}$ \\
\hline
\end{tabular}

Further research such as purification of the enzymes from the two chemotypes, as well as isolation and analysis of their respective genes will aid in answering the question whether the methylation of both substrates ( $\mathrm{t}$-anethol and chavicol ) are catalyzed by one 'bispecific' OMT (OMethyltransferase) or by two distinct enzymes but similar forms of the enzymes. O-methylation at the $\mathrm{OH}$ group, in the last biosynthetic step involved in the formation of fennel volatile phenylpropenoids, cannot solely account for the difference in estragole and anethole composition of the chemotypes (Gross et al., 2002).

\section{Conclusions}

The results showed that $2,4-\mathrm{D}$ at $0.5 \mathrm{mg} / \mathrm{l}$ plus kinetin at $1 \mathrm{mg} / \mathrm{l}$ produced the best response in callus induction. It may activate especial enzyme which carry out the double bond from conjugated trans configuration (trans-anethole) to non conjugated double bond (estragole) or vice- versa, of course these point needs further investigation to approve our suggestion. Finally, from the presented data, it can be concluded that the seedlings which produced from the callus induced from root on MS media free hormone were the best for cultivation, and it could be induced into a breeding program in the future for commercial production.

\section{Acknowledgments}

Authors would like to thank the management of the Faculty of Agriculture and, Cairo University for ongoing cooperation to support research and that provided funds and facilities necessary to achieve the desired goals of research.

\section{References}

Adams RP (2001). Identification of essential oils compounds by gas-chromatography/quadrupole mass spectrometry. Allured Publishing Corporation, Carol Stream, IL, USA.

A E B (2007). Agric. Economic. Bull January, Edited by Dept. of Agric. Economic and Statistic Ministry of Agric. ARE.

Akgül A, Bayrak A (1988). Comparative volatile oil composition of various parts from Turkish Bitter Fennel (Foeniculum vulgare var. vulgare). Food Chemistry 30:319-323.

Arslan N, Bayrak A, Akgul A (1989). The yield and components of essential oil in fennels of different origin (Foeniculum vulgare Mill.) grown in Ankara conditions. Herba Hungarica 28(3):27-31.

Ashraf M, Bhatty MK (1975). Studies on the essential oils of the Pakistan species of the family Umbelliferae. Part $\Pi$ Foeniculum vulgare Miller (fennel) seed oil Pak. J Sci Ind Res 18(5):236-240.

Baldrich A M, Castańo R, Baluja R (1986). Estudio de los aceites esenciales obtenidos de differentes partes de la planta de Hinojo dulce cultivada en Cuba. Rev Cub Farm 20:101106.

Barazani O, Fait A, Cohen Y, Diminshtein S, Ravid U, Putievsky E, Lewinsohn E, Friedman J (1999). Chemical variation among indigenous populations of Foeniculum vulgare var. vulgare in Israel. Planta Med 65:486-489.

Barazani O, Cohen Y, Fait A, Diminshtein S, Dudai N, Ravid U, Putievsky E, Friedman J (2002). Chemotypic differentiation in indigenous populations of Foeniculum vulgare var. vulgare in Israel. Biochemical Systematics and Ecology 30:721-731.

BernathJ,NemethE, Kattaa A,HethelyiE (1996).Morphological and chemical evaluation of fennel (Foeniculum vulgare Mill.) populations of different origin. J Essent Oil Res 8:247-253.

Bilia AR, Fumarola M, Gallori S, Mazzi G, Vicieri FF (2000). Identification by HPLC-DAD and HPLC-MS analyses and quantification of constituents of fennel teas and decoctions. J Agric Food Chem 48(10):4734-4738.

Bilia AR, Flamini G, Taglioli V, Morelli I, Vincieri FF (2002). GC-MS analysis of essential oil of some commercial fennel 
86 teas. Food Chem 76(4):307-310.

Burkhard PR, Burkhardt K, Haenggeli CA, Landis T (1999). Plant induced seizures: reappearance of an old problem. J Neurol 246:667-670.

Davis PH (1972). Flora of Turkey and the East Aegean Islands, vol.4 University Press, Edinburgh.

El-Keltawi NE, Cratean R (1987). Influence of foliar applied cytokinins on growth and essential oil content of several members of the Laminaceae. Phytochemistry 26(4):891985.

Embong MB, Hadziyer D, Molnar S (1977). Essential oils from spices grown in Alberta Fennel oil (Foeniculum vulgare var. dulce). Can J Plant Sci 57:829-837.

Fenaroli C (1971). "Fenaroll's Hand Book of Flavor Ingredients" The chemical, Rubber Company 1891 Cran Wood ParkWay, Clereland, Ohio 44128, USA.

Gross M, Friedman J, Dudai N, Larkov O, Cohen Y, Bar E, Ravid U, Putievsky E, Lewinsohn E (2002). Biosynthesis of estragole and t-anethole in bitter fennel (Foeniculum vulgare Miller var. vulgare) chemotypes. Changes in SAM: phenylpropene O-methyltransferase activities during development. J Plant Science 163:1047-1053.

Halperin W, Wetherell DF (1964). Adventive embryony in tissue cultures of the wild carrot, Daucus carota. Am J Bot 51:274-283.

Kim DH, Ahn YJ (2001). Contact and fumigant activities of constituents of Foeniculum vulgare fruit against three coleopteran stored-product insects. Pest Management Science 57:301-306.

Massoud H (1992). Study on the essential oil in seeds of some fennel cultivars under Egyptian Environmental Conditions. Planta Med 58(7):681-682

McDonald TA (1999). Evidence on the carcinogenicity of Estragole. Reproductive and Cancer Hazard Assessment Section, Office of Environmental Health Hazard Assessment, California Environmental Protection Agency.

Miraldi E (1999). Comparison of the essential oils from ten Foeniculum vulgare Miller samples of fruits of different origin. J Flavour and Fragrance 14(6):379-382.

Muckensturm B, Foechterln D, Reduron JP, Danton P, Hildenbrand M (1997). Phytochemeical and chemotaxonomic Studies of Foeniculumvulgare. Biochemical Systematics and Ecology 25(4):353-358.
Murashig T, Skoog F (1962). A revised medium for rapid growth and bioassays with tobacco tissue cultures. Physiol Plant 15:473-497.

Nadel BL, Altman A, Ziv M (1989). Regulation of somatic embryogenesis in celery cell suspensions, promoting effects of mannitol on somatic embryo development. Plant Cell, Tissue and Organ Culture 18(2):181-189.

Phillips DH (1994). DNA adducts derived from safrole, estragole and related compounds, and from benzene and its metabolites, p. 131-140. In: DNA Adducts Identification and Biological Significance, IARC Scientific Publications, International Agency for Research on Cancer, Lyon, France.

Saleh MM, Hashem FA, Grace MH (1996). Volatile oil of Egyptian sweet fennel (Foeniculum vulgare var. dulce, Alef.) and its effects on isolated smooth muscles. Pharm Pharmacol Lett 6:5-7

Sangwan NS, Farooqi AHA, Shabih F, Sangwan RS (2001). Regulation of essential oil production in plants. Plant Growth Regulation 34:3-21.

Saranga Y, Janick J (1991). Celery somatic embryo production and regeneration: Improved protocols. Hort Science 26(10):1335.

Schive JB, Sisler HD (1976). Effect of ancymidol (a growth retardant) and triarimol (a fungicide) on the growth, sterols, and gibberelline of Phaseolus vulgaris L. Plant Physiol 57:640-644

Venskutonis PR, Dapkevicius A, Van Beek TA (1996). Essential oils of fennel (Foeniculum vulgare Mill.) from Lithuania. J Essent Oil Res 8(2):211-213.

Tawfik AA (1995). Plant regeneration in callus culture of cumin. Acta Horticulture 457:389-393.

Vincenzi M, Silano M, Maialetti F, Scazzocchio B (2000). Constituents of aromatic Plants: $\Pi$ Estragole. Fitoterapia 71:725-729.

Youssef AA, Iman MT (1998). Physiological effect of brassinosteroid and kinetin on the growth and chemical constituents of lavender plant. Annals of Agricultural Science Cairo 43(1):261-272. 